\title{
Experimental Investigation of Evaporation and Condensation in a Sandy Soil under Simulated Arid Conditions
}

\section{Eiichi SHIMOJIMA 1) Ichiro TAMAGAWA 2) Jeffrey V. TURNER ${ }^{3)}$}

\author{
1) Daido University \\ (40 Hakusui-cho, Minami-ku, Nagoya 457-8532 Japan)
}

2) River Basin Research Center, Gifu University

(1-1 Yanagido, Gifu 501-1193 Japan)

3) CSIRO Land and Water

(PO Wembley 6913, Western Australia)

In order to elucidate water vapour behaviour in soil in arid regions due to the diurnal cycle of meteorological conditions, column experiments using a saline sandy soil from Western Australia were undertaken under controlled atmospheric conditions. The upper surface of the sand column was exposed to conditions of constant temperature $\left(25^{\circ} \mathrm{C}\right)$ and constant relative humidity changed stepwise from $20 \%$ to $65 \%$ and vice versa with or without applied radiated heat. Furthermore, experimental cases in which the heat application only was given stepwise and stopped under the $65 \%$ relative humidity atmospheric condition, corresponding to daytime and night-time, were also conducted.

When only atmospheric humidity was changed stepwise, the soil vapour density, $\rho_{v}$, followed a function of $x / \sqrt{t}(x:$ depth, $t$ : elapsed time). This characteristic, and related results were explained through a modified vapour diffusion equation in $\rho_{v}$ under an isothermal condition proposed in this paper. Comparison of experimentally determined vapour diffusivity with a model calculation showed that evaporation and condensation within the profile significantly retarded the movement of water vapour density profile as a breakthrough curve.

The above obtained characteristic behaviours of vapour water are important in understanding the water transfer between the ground surface and atmosphere as well as that in the soil profile, in arid areas.

Key words: evaporation, condensation, arid zone, water vapour transport, soil column experiments.

\section{I . INTRODUCTION}

When near-surface soils in semi-arid and arid areas become extremely dry, evaporation ceases to occur at the soil surface and the location of the evaporating front migrates downwards because the atmospheric evaporation demand is greater than the ability of the soil to conduct the liquid water to the ground surface. The cyclical condensationevaporation process is one of the important boundary conditions for thermal and moisture flux conditions at the ground surface in atmosphere-land systems (e.g. Chanzy and Bruckler, 1993). At the diurnal time scale, Yamanaka and Yonetani (1999) demonstrated that condensation-evaporation cycles occurred based on stable isotope and water content profiles under specific field conditions. They showed that the condensation of soil water vapour traveling upward in the profile occurs during the night due to atmospheric temperature decrease via radiative cooling, and that some or all of the 
condensed water vapour was lost from the soil profile and transferred into the atmosphere via evaporation during daytime. The condensed water can subsequently become the source of evaporation. Recently, Zhang et al. (2003) demonstrated soil vapour condensation from field evidence in the Gobi desert, demonstrating a "respiration" process where atmospheric moisture condensed in the soil profile during the night was subsequently re-evaporated during the daytime. The field data of Zhang et al. (2003) however, did not allow the estimation of net hydrological transfers via this mechanism. Mitsuta et al. (1995) have examined the evaporation-condensation process meteorologically through measurement of turbulent transfer of vapour on sandy dunes in Western China and estimated the amount of condensed water during the night to be of the order of $10^{-2}-10^{-3} \mathrm{~mm}$. By direct soil sampling and micro-lysimetry Agam and Berliner (2004) observed the amount of condensed water in the Negev desert to be in the range $0.2-0.3 \mathrm{~mm} / \mathrm{night}$.

Although the net amount of water vapour sequestered from the atmosphere is not necessarily large, its role is very important for understanding water balance in extremely dry environments, and potentially it plays a critical role in the viability of vegetation in arid zones and their associated or dependent ecosystems. Little research has been done on the evaporation-condensation mechanism, particularly with regard to its potential as a mechanism for net sequestration of atmospheric water vapour in arid regions (e.g. Shimojima et al., 2010).

In this paper, in order to investigate mechanisms of condensation and evaporation in semi-arid or arid regions from a fundamental aspect, laboratory experiments using dry soil columns have been undertaken by applying a simple boundary condition such as a stepwise varied atmospheric condition to the exposed soil surface, in particular focusing on the behaviour of water vapour in the soil.

\section{II . THEORETICAL BACKGROUND}

It is difficult to directly and continuously measure the behaviour of soil-water in the liquid phase in a dry soil layer in arid area. Accordingly, this paper focuses on the theoretical and experimental behaviour of the continuously measurable behaviour of water vapour in the soil profile which is amenable experimentally by sensors that continuously monitor humidity and temperature as stated in the next Section.

\section{Fundamental equation for water vapor distribution - proposed model for vapour movement}

The vapour movement in the soil layer follows Fick's law as (Philip and de Vries, 1957):

$$
F_{v}=-D_{v} \frac{\partial \rho_{v}}{\partial x}
$$

where $F_{\mathrm{v}}$ is the flux density for the vapor, $\rho_{v}$ is vapor density, $x$ is depth, $D_{v}$ the effective molecular diffusivity for the vapour and approximated by $D_{v}=D_{v 0} \theta_{a} \tau$ (Barnes and Allison, 1984). $\theta_{a}$ is air-filled porosity, $\tau$ tortuosity $(=2 / 3)$ and $D_{v_{0}}\left(\mathrm{~cm}^{2} / \mathrm{s}\right)$ the molecular diffusivity for the vapor, depending on absolute temperature, $T$ as (de Vries, 1963):

$$
D_{v 0}=\frac{17.6}{76}\left(\frac{T}{273}\right)^{2.3}\left(\mathrm{~cm}^{2} / \mathrm{s}\right)
$$

In Equation (1) the turbulence of airflow over the upper surface of the soil layer was assumed to be very weak (Ishihara et al., 1992).

The continuity equation for the water vapour and the liquid water are described as:

$$
\frac{\partial\left(\theta_{a} \rho_{v}\right)}{\partial t}+\frac{\partial F_{v}}{\partial x}=\varepsilon
$$

and

$$
\rho_{w} \frac{\partial \theta}{\partial t}=-\varepsilon
$$

respectively, where $\theta$ is volumetric water content and $\varepsilon$ is the strength of evaporation $(>0)$ or 
condensation $(<0)$ per unit volume and time, $\rho_{w}$ liquid water density, and in Equation (4), the water in the soil layer assumed to hardly move in the liquid phase, because the layer condition was set to be fairly dry as stated later.

By taking account that $\theta_{a}+\theta=$ constant, eliminating $\varepsilon$ term from Equations (3) and (4) yields:

$$
\begin{aligned}
& \theta_{a} \frac{\partial \rho_{v}}{\partial t}+\frac{\partial F_{v}}{\partial x}=-\left(\rho_{w}-\rho_{v}\right) \frac{\partial \theta}{\partial t} \\
& \approx-\rho_{w} \frac{\partial \theta}{\partial t}
\end{aligned}
$$

because $\rho_{w} \gg \rho_{v}$.

The Kelvin's equation describing the equilibrium relation between the pore-air phase and its adjoining liquid-water in soil is given by (Philip and de Vries, 1957):

$$
h=\frac{\rho_{v}}{\rho_{v, s}}=\exp \left(\frac{\psi g}{R T}\right)
$$

where $\rho_{v, s}$ is the saturated water vapour density, $\psi$ the matric potential in height $(\mathrm{cm}), R$ the gas constant for unit mass of water vapor $(=4.615 \times$ $\left.10^{6} \mathrm{erg} / \mathrm{g} / \mathrm{K}\right)$ and $g$ the gravitational acceleration $\left(\mathrm{cm} / \mathrm{s}^{2}\right)$.

Under assumption that $\psi$ is a unique function of $\theta$ and $(\partial T / \partial t)$ is negligibly small, combining Equation (6) with Equation (7) yields (see Appendix A-1):

$$
\left(\theta_{a}+\rho_{w} \beta\right) \frac{\partial \rho_{v}}{\partial t}+\frac{\partial F_{v}}{\partial x}=0
$$

where $\quad \beta=\left(\frac{1}{\rho_{v}}\right)^{\frac{R T}{g}} \frac{\frac{R}{d \theta}}{d \theta}$

Furthermore, if temperature in soil layer varies sufficiently slowly with respect to $x$, substitution of Equation (1) into Equation (8) yields the fundamental equation describing behaviour of vapour density as:

$$
\frac{\partial \rho_{v}}{\partial t}=D_{v, m} \frac{\partial^{2} \rho_{v}}{\partial x^{2}}
$$

where

$$
D_{v, m}=\frac{D_{v}}{\theta_{a}+\rho_{w} \beta}=\frac{D_{v 0} \tau \theta_{a}}{\theta_{a}+\rho_{w} \beta},
$$

Putting of $\varepsilon=0$ to Equation (4) yields that $\theta_{a}$ is constant. And when $\varepsilon=0$ is applied to Equation (3) combined with Equation (1), the resultant equation becomes Equation (10) where $D_{\mathrm{v}}, \mathrm{m}$ (Equation (11)) is set with $\beta=0$. That is, this indicates that $\rho_{v}$ could be unlinked to $\theta$. Therefore the parameter, $\beta$, indicates the effects of evaporation and condensation. Overall, Equation (10) gives the modified diffusion equation for water vapor movement in a uniform soil layer, i.e. simplified mathematical model for describing vapor movement.

\section{Initial and boundary conditions and solutions}

By referring to experimental conditions shown later, the initial and boundary conditions are set:

$$
\begin{aligned}
& \rho_{v}=\rho_{v 0}=\text { const. }, \quad \text { at } t=0 \text { for } x>0 \\
& \rho_{v}=\rho_{v 1}=\text { const. }\left(\neq \rho_{v 0}\right), \quad \text { at } x=0 \text { for } t>0
\end{aligned}
$$

where $\rho_{v 0}$ and $\rho_{v 1}$ mean $\rho_{v}$-values set initially in the sand column and on its upper surface during the experiment, respectively.

For the sake of a more general treatment, by defining the non-dimensional modified vapor density, $\rho_{v}{ }^{*}$ as

$$
\rho_{v}^{*}=\frac{\rho_{v}-\rho_{v 0}}{\rho_{v 1}-\rho_{v 0}}
$$

the fundamental equation (Equation (10)) and the initial-boundary conditions (Equation (12)) become:

$$
\frac{\partial \rho_{v}{ }^{*}}{\partial t}=D_{v, m} \frac{\partial^{2} \rho_{v}{ }^{*}}{\partial x^{2}}
$$

and

$$
\begin{array}{lll}
\rho_{v}{ }^{*}=0 & \text { at } t=0 & \text { for } x>0 ; \\
\rho_{v}{ }^{*}=1 & \text { at } x=0 & \text { for } t>0
\end{array}
$$

respectively. 
If $D_{v, m}$ in Equation (14) is set constant, then an analytical solution of Equation (14) under the conditions of Equation (15) can be obtained as (e.g. Crank, 1975):

$$
\rho_{v}^{*}=\operatorname{erfc} \lambda
$$

where

$$
\lambda=\frac{x}{2 \sqrt{D_{v, m}} t}=\frac{\xi}{2 \sqrt{D_{v, m}}}
$$

In here $\xi=\frac{x}{\sqrt{t}}$. The similarity solution, Equation (17), gives the variable characteristic of the vapor density profile applicable to the experiments shown later.

\section{MATERIALS AND METHODS}

\section{Materials used}

The porous material, a sandy soil, used in the experiments was taken from a salinized surface soil layer at the CSIRO Yalanbee experimental field site (lat. $31^{\circ} 76^{\prime} \mathrm{S}$; lon. $116^{\circ} 48^{\prime}$; elev. $330 \mathrm{~m}$ ), Bakers Hill, Western Australia. This was screened through a $2.38 \mathrm{~mm}$ mesh sieve because the field soil had a wide range in particle-size distribution from greater than $2 \mathrm{~mm}$ to silt size. Its medium particle size was $0.55 \mathrm{~mm}$ and the air-entry-value was $-10 \mathrm{~cm}$ water head.

The sandy soil was air-dried at $20 \%$ relative humidity and $25{ }^{\circ} \mathrm{C}$ and packed uniformly into PVC columns $10 \mathrm{~cm}$ diameter and $100 \mathrm{~cm}$ long, with a supporting base plate. The prepared columns were positioned vertically on a floor and their sides were covered with an adiabatic mat.

\section{Experimental conditions}

In order to examine evaporation and condensation mechanisms which are considered to occur diurnally in extremely dry areas, the sandy soil column experiments were conducted under several atmospheric conditions summarized in Table 1 and in the absence of a water-table. All experiments were undertaken in a temperature and humidity controlled room where the air temperature was maintained at $25{ }^{\circ} \mathrm{C}$, and humidity was controlled
Table 1 Summary of experimental conditions. 表 -1 実験条件

\begin{tabular}{l|c|c|c}
\hline Case & $\begin{array}{c}\text { Initial Humidity (\%) } \\
\text { in Column }\end{array}$ & $\begin{array}{c}\text { Atmospheric } \\
\text { Humidity (\%) }\end{array}$ & $\begin{array}{c}\text { Applied Heat } \\
\text { Radiation } \\
550 \mathrm{~W} / \mathrm{m}^{2}\end{array}$ \\
\hline $\mathrm{A}(1)$ & 20 & 65 & no \\
$\mathrm{A}(2)-1$ & 65 & 20 & no \\
$\mathrm{A}(2)-2$ & 65 & 20 & yes \\
$\mathrm{A}(3)-1$ & 65 & 65 & yes \\
$\mathrm{A}(3)-2$ & $\begin{array}{c}\text { Continued from } \\
\mathrm{A}(3)-1\end{array}$ & 65 & no \\
\hline
\end{tabular}

according to the experimental requirements.

Evaporation or condensation of water vapour under simulated day-time or night-time conditions was examined in the experiments (hereafter denoted to 'Case A'). The initial humidity status of the sand columns was established by drawing ambient air through them at $25{ }^{\circ} \mathrm{C}$ and at either 20 $\%$ or $65 \%$ relative humidity (designated $\mathrm{RH}_{20}$ and $\mathrm{RH}_{65}$ respectively in the following). The upper surface of the respective column was then sealed with a plastic cover while the incident atmospheric $\mathrm{RH}$ to the column surface was changed to the required $\mathrm{RH}$ value, $\left(\mathrm{RH}_{65}\right.$ or $\left.\mathrm{RH}_{20}\right)$, whence the experiment was commenced by removing the cover. In Case A(2)-2 heat radiation of $550 \mathrm{~W} / \mathrm{m}^{2}$ was applied continuously via an infra-red lamp to the upper surface of the sand column for the duration of the experiment. In Case A(3)-1 the humidity was held constant in order to examine the influence of temperature only on vapour behaviour. Case A(3)-2 was the continuation of A(3)-1 following cessation of the applied heat radiation. Overall, Cases A(1) and A(3)-2 are for the simply modeled night-time condition. The former simulates that ground surface is exposed to more moist atmosphere and the latter simulates that soil heated during daytime is cooled by stop of solar radiation. Cases $\mathrm{A}(2)-1$ and $\mathrm{A}(2)-2$ are reversely for the simply modeled day-time condition. The former simulates that the ground surface is exposed to drier atmosphere and the latter also simulates further with solar radiation. And A(3)-1 simulates for day-time condition, too, but only for the effects of solar radiation. 


\section{Measurements}

Humidity sensors ( $8 \mathrm{~mm}$ diameter, Vaisala, HMP36ASF) were inserted through the column side-wall into the upper sections of the sand column to directly measure the in situ temperature and humidity. Those located at 1.0, 2.0, 3.3, 5.3, 8.7, 11.8 and $15.2 \mathrm{~cm}$ deep from the upper surface of the sand column. During the experiment, these data were taken at every 15 minutes and stored in data-recorders (HMI 36, Vaisala).

\section{IV . EXPERIMENTAL RESULTS AND ANALYSIS}

\section{Observed results}

Fig. 1(a) - (c) show variations in modified water vapour density, $\rho_{v}{ }^{*}$, at specific depth $(x)$, with modified time, $\frac{x}{\sqrt{t}}(=\xi)$ for Cases $\mathrm{A}(1)$ and (2), where $t$ is elapsed time and $\rho_{v}{ }^{*}$ has been defined previously in Equation (13) as $\rho_{v}{ }^{*}=\left(\rho_{v}-\rho_{v 0}\right) /\left(\rho_{v 1}-\rho_{v 0}\right)$. Additionally, $\rho_{v 0}$ and $\rho_{v l}$ are the initial and the applied atmospheric values of $\rho_{v}$, respectively. For Case A(1), (Fig. 1(a)) where an initially dry sand at $\mathrm{RH}_{20}$ was exposed to humid air at $\mathrm{RH}_{65}$, the data for all depths were not fully consistent with each other as $\xi$ for a specific value of $\rho_{v}{ }^{*}$ became small with decreasing depth, although not strictly in order of depth. The location of the curves of $\rho_{v}^{*}$ vs. $\xi$ for all measurements are almost in the expected sequence according to their depths. This trend indicates that on the scale of $\left(\frac{x}{\sqrt{t}}\right)$, it takes more time to increase to a specified value of $\rho_{v}{ }^{*}$ (or $\rho_{v}$ ) with decreasing depth.

For Case A(2)-1, (Fig. 1(b)) where the initially humid sand $\left(\mathrm{RH}_{65}\right)$ was exposed to dry air $\left(\mathrm{RH}_{20}\right)$, the data for several depths plot on almost the same curve. Comparison between the changes of $\rho_{v}{ }^{*}$ with $\xi$ for Case $\mathrm{A}(1)$ and Case A(2)-1 suggests that both almost overlap for larger $\xi$, but for smaller $\xi$ the former (in particular at shallower locations) was located at lower $\rho_{v}{ }^{*}$. For Case A(2)-2, (Fig. 1 (c)) where the sand at $\mathrm{RH}_{65}$ was exposed to dry air $\left(\mathrm{RH}_{20}\right)$ as in Case A(2)-1 with radiative heating, the changes in $\rho_{v}^{*}$ with $\xi$ were similar to those for
Fig.1 (a)

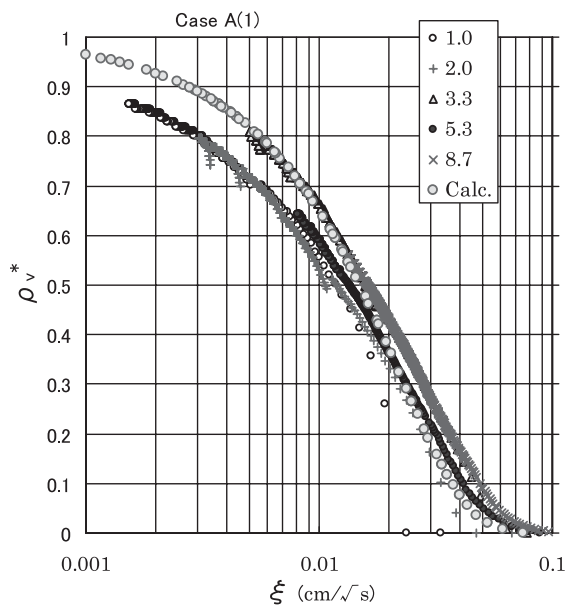

Fig.1 (b)

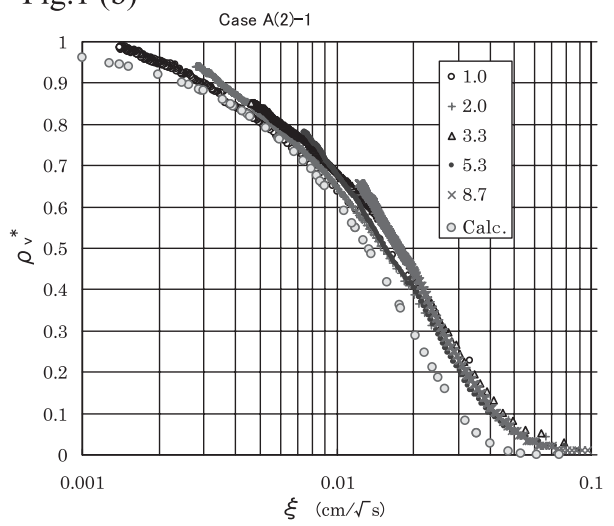

Fig.1 (c)

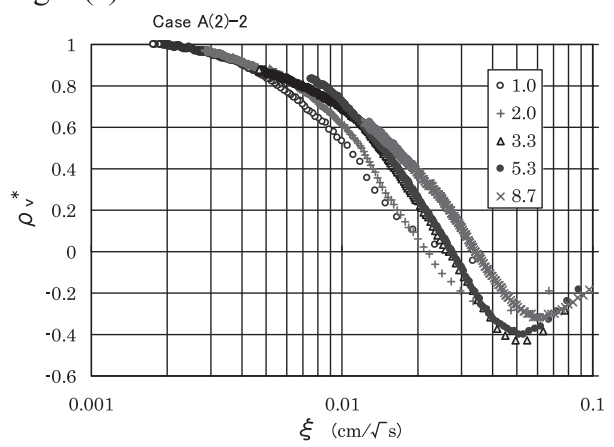

Fig. 1 (a) CaseA (1), (b) Case A(2)-1, (c) Case A(2)-2. Relations between $\rho_{v}{ }^{*}$ and $\xi\left(=\frac{x}{\sqrt{t}}\right)$, showing transient vapour density changes with depth and time. The legend shows the depth of measurement $x(\mathrm{~cm})$. "Calc". represents results of simulations using Equation 14.

図 - 1 (a) Case A (1), (b) Case A (2)-1, (c) Case A (2) -2. 深さと時間方向への水蒸気密度の変化を示す $\rho_{v}{ }^{*}$ と $\xi\left(=\frac{x}{\sqrt{t}}\right)$ との関係図. 凡例は計測深度 $x(\mathrm{~cm})$ を示 す。“Calc.”は，式14を用いた計算結果である。 
A(2)-1 but the degree of difference between curves for each depth was larger. Note that $\rho_{v}^{*}$ in the early stages (i.e. for larger $\xi$ ) became negative and has a minimum of -0.3 to -0.4 . As the negative sign corresponds to an increase in vapour density from its initial state, caused by evaporation due to the increased temperature of the sand column from the radiative heat applied to its upper surface.

\section{Analysis and considerations}

1) Effects of evaporation and condensation on vapour movement

For practical examination of the effects, the location at which $\rho_{v}^{*}=0.5$ is, from now on, considered as a representative point in the vapour density profile, because examination of observed results using several $\rho_{v}^{*}$-values becomes very complicated and it is considered that the profile of $\rho_{v}^{*} \sim \xi$ may become more or less symmetric with respect to $\rho_{v}^{*}=0.5$.

In Fig. 1, the $\xi$-value for $\rho_{v}^{*}=0.5$ was estimated to occur in the range $0.011-0.015 \mathrm{~cm} / \mathrm{s}^{1 / 2}$ for Case $\mathrm{A}(1), 0.015-0.017 \mathrm{~cm} / \mathrm{s}^{1 / 2}$ for Case $\mathrm{A}(2)-1$ and $0.0108-0.016 \mathrm{~cm} / \mathrm{s}^{1 / 2}$ for Case A(2)-2. An analytical solution for the approximate (modeled) equation, Equation (14), governing the water vapour movement in the soil profiles is given by Equation (16) where $\rho_{v}^{*}=0.5$ corresponds to a $\lambda$ value of 0.475 in Equation (16), therefore $D_{v, m}=[\xi /(2 \times 0.475)]^{2}$ (see Equation (17)). Though $\left(D_{v} / \theta_{a}\right)$ defined newly as $K_{v, a}$ corresponds to $D_{v, m}$ (see Equation (11)), numerical estimation of $D_{v} / D_{v, m}$ is undertaken as follows. That is, if $D_{v 0}$ $=0.283 \mathrm{~cm}^{2} / \mathrm{s}$ (at $\left.25{ }^{\circ} \mathrm{C}\right), \tau=2 / 3$ and $\theta_{a}=0.4$ are used in $D_{v}=D_{v 0} \times \theta_{a} \times \tau$, then $D_{v} / D_{v, m}=(5.63-3.02) \times$ $10^{2}$ for $\mathrm{A}(1),(3.02-2.36) \times 10^{2}$ for $\mathrm{A}(2)-1$ and $(5.81-2.67) \times 10^{2}$ for $\mathrm{A}(2)-2$, where $D_{v}=7.55 \times 10^{-2}$ $\mathrm{cm}^{2} / \mathrm{s}$. The obtained fact that $D_{v, m} \ll\left(D_{v} / \theta_{a}\right)\left(\theta_{a}=0.4\right)$, indicates the important point that the modeled vapour transport becomes much slower when the occurrence of evaporation or condensation in the sand column is neglected.

Values of $D_{v} / D_{v, m}$ obtained above using experimental data are consistent with the value of $\rho_{w} \beta$ (see Equation (11)), 300 - 500, estimated theoretically in the Appendix A-2. Therefore, it is concluded that $D_{v, m}\left(=\left(D_{v 0} \tau \theta_{a}\right) /\left[\theta_{a}+\rho_{w} \beta\right]\right)$ can be approximated by $\left(D_{v 0} \tau \theta_{a}\right) /\left(\rho_{w} \beta\right)$, with its calculated value of $(1.5-2.5) \times 10^{-4} \mathrm{~cm}^{2} / \mathrm{s}$, and $\left(K_{v, a} / D_{v, m}\right)$ becomes $750-1250(\approx 1,000)$. In conclusion, the observed vapour transport was slower than can be accounted for if evaporation and condensation are not considered to be occurring in the profile.

\section{2) Characteristics of vapour density profile}

During the evaporation and condensation process, RH marked by $h$ in the sand column was varied between $0.2<h<0.65$. $D_{v, m}$ decreases with increasing $h$ within the applied range of $\mathrm{RH}$ because $h$ at the minimum $\beta$, was about 0.3 (see Appendix A-2).

The relation between $\rho_{v}^{*}$ and $x / \sqrt{t}$ for several $x$ values was examined and all the data was seen to plots on a similar curves as in Fig. 1 (a)-(c). Results of numerical simulation of Equation (14) are shown using circular symbols (labeled 'Calc.') in Fig. 1(a) and (b), where used values of its model parameters are shown in Appendix A-2. In fact the $\beta$, strictly speaking, depending on $h$ is given by Fig. A1 but it is known that its calculated $\rho_{v}^{*}(x / \sqrt{t})$ profile is more or less consistent with those for constant $\beta$-value such as 300 and 500. The calculated values closely follow the experimentally observed results. In detail, for Case A(2)-1, the calculated results are consistent with the experimental ones for $\rho_{v}{ }^{*}>0.5$ but for $\rho_{v}{ }^{*}<0.5$ they are located slightly to the left, i.e. the calculated drying process was delayed relative to the observed. On the other hand, for Case A(1), for $\rho_{v}{ }^{*}>0.5$ the calculated results almost overlap with the observed at greater depths $(x=3.3,8.7$ $\mathrm{cm})$ but for $\rho_{v}{ }^{*}<0.5$ the modeled results are consistent with the observed ones at shallower depths $(x=1,2 \mathrm{~cm})$. Overall, it is concluded that observed $\rho_{v}^{*}$ profiles are consistent well with the calculated one.

Fig. 2 shows changes in $\rho_{v}$, with the square root of time for Case A(3)-1, where the sand initially at $\mathrm{RH}_{65}$ was exposed to humid air $\left(\mathrm{RH}_{65}\right)$ with 


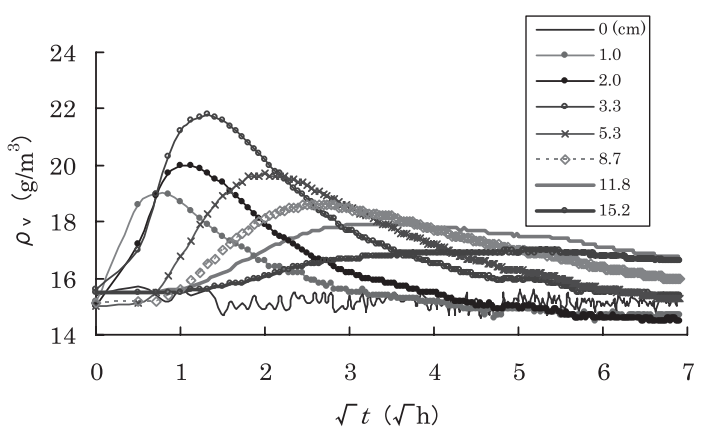

Fig. $2 \rho_{v}$ vs. $\sqrt{t}$ (Case A(3)-1). The legend indicates the depth of measurement $(\mathrm{cm})$.

図-2 $\rho_{v}$ と $\sqrt{t}$ の関係 (Case A (3) - 1) . 凡例は計測深度 (cm) を示す.

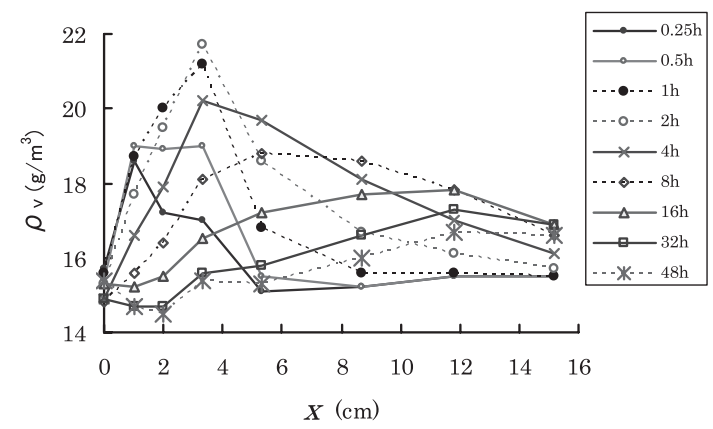

Fig. 3 Temporal change in water vapour density profiles for Case A(3)-1.

図-3 Case A (3)-1に拈ける水蒸気密度プロファイル の時間変化

radiative heating. Initially the vapour density was uniformly distributed with depth at about $15 \mathrm{~g} / \mathrm{m}^{3}$ and varied with time in an upward convex shape. Its time-to-peak occurred progressively later with increasing depth. The peak became higher with increasing depth $(x)$ for $x<3.3 \mathrm{~cm}$, while, conversely, it declined for $x>3.3 \mathrm{~cm}$. Because $\rho_{v}$ became larger than $\rho_{v 0}$ at early stages, this explains the appearance of negative values of $\rho_{v}^{*}$ in Fig. 1(c) for Case A(2)-2.

Development of vapour density profiles with depth for A(3)-1 are shown in Fig. 3. The location of the peak divides the direction of vapour movement because the density gradient drives vapour movement, thus the zone of upward movement expands with time. Overall, appearance of peak in $\rho_{v}$ profiles with higher concentration

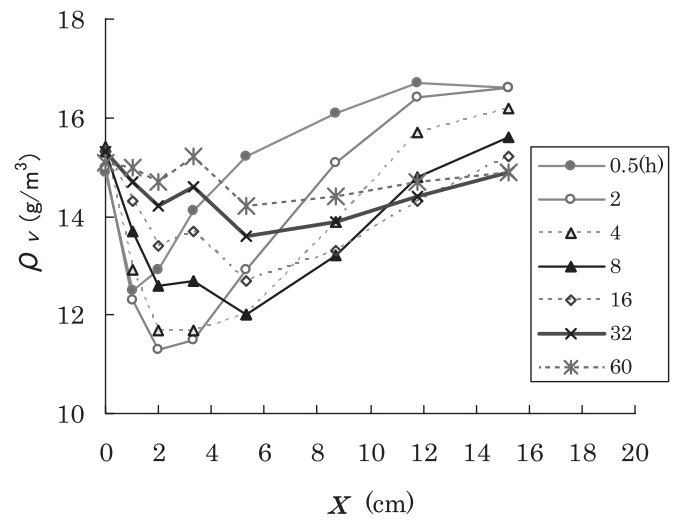

Fig. 4 As for Fig. 3, but for Case A(3)-2: Temporal change in vapour density profiles following cessation of radiative heating.

図-4 Case A(3)-2に対する図-3同様の図. 放射加熱 の停止後の水蒸気密度プロファイルの時間変化 を示す。

than an initial state suggests that some amount of vapour generated via evaporation by that heating is added to pore-air phase around its location and the residual is transported toward upward and downward directions. Analogous phenomenon to the evaporation-vapour transfer process is considered to occur during daytimes in the field.

At the end of Case A(3)-1, the profile was distributed almost uniformly at approximately $15.0-16.6 \mathrm{~g} / \mathrm{m}^{3}$. The temporal variation in the $\rho_{v}$ profile after cessation of radiative heating on the surface is shown in Fig. 4. A trough in $\rho_{v}$ was present for any given time in the profile and its location moved downward from $1 \mathrm{~cm}$ to $5 \mathrm{~cm}$ depth with time. The vapour density at the trough dropped abruptly ( 2 hours) to a smaller value than the initial value $\left(\rho_{v 0}\right)$ and then increased with time. It is concluded that the abrupt drop and the increasing tendency in $\rho_{v}$ are due to condensation on the soil surface and vapour movement from both sides of the trough in $\rho_{v}$, respectively. That is, vapour in near-sand surface zone is condensed due to soil-temperature lowering after cessation of the heating as stated later (see Fig. 5) and its location moves downwards with time (also see Fig. 6), and simultaneously, lost vapour is supplied toward the original state (under the initial condition 
for Case A(3)-1) by invading atmospheric vapour as well as upward transported vapor from a deeper zone. It may be considered that these condensation vapour transport process occur during nighttime in soil layer.

\section{3) Change in soil-temperature with time}

Fig. 5(a) and (b) show changes in temperature with time for Cases A(3)-1 and A(3)-2, respectively. For Case A(3)-1; temperature was initially distributed uniformly with depth, but started to increase in response to the radiative heating on the upper surface of the sand column and this response occurred more rapidly at shallower depths. The increasing trend at $x<15$ $\mathrm{cm}$ ceases at around $t=4 \mathrm{~h}-6 \mathrm{~h}\left(\sqrt{t}=2-2.5 \mathrm{~h}^{1 / 2}\right)$ and a temperature distribution profile with negative slope (i.e., $\partial T / \partial x<0$ ) is formed.

The temperature in the sand column decreases

Fig. 5 (a)

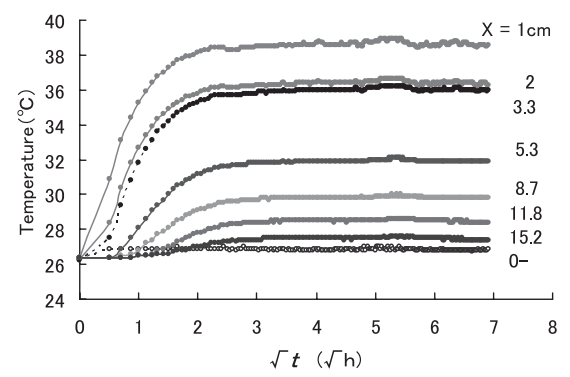

Fig. 5 (b)

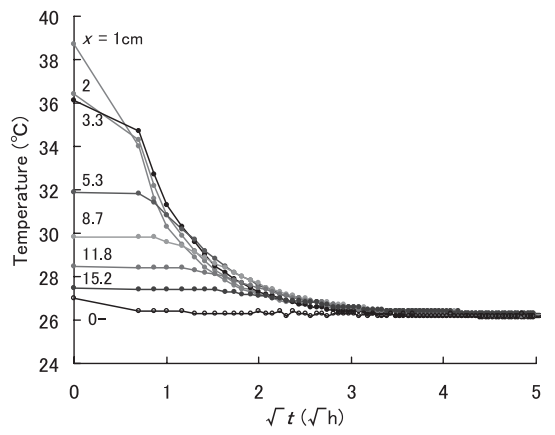

Fig. 5 (a) Case A(3)-1, (b) Case A(3)-2: Temporal changes in temperature in the sand column, where " 0 " indicates the atmospheric temperature.

図-5 (a) Case A (3) -1, (b) Case A (3) -2 : 砂カラム中 の温度の時間変化. “0”は気温を示す. linearly from $T \approx 45{ }^{\circ} \mathrm{C}$ at $x=0_{+}$to $T=26{ }^{\circ} \mathrm{C}$ (almost ambient temperature) at around $15 \mathrm{~cm}$ depth over a short period of about 4 hours. These transient characteristic was also seen for Case $\mathrm{A}(2)-2$. For Case A(3)-2; this initial temperature distribution was the quasi-steady profile formed in Case A(3)-1. As soon as the radiative heating in Case A(3)-1 was stopped, the elevated temperature started to decrease and approached a uniform profile at the ambient temperature, where the rate of decrease was faster at shallower locations and the temperature distribution became uniform within 6 hours.

\section{4) Migration of the evaporation and condensation zones}

As stated previously, thermal heating was applied to the column surface in Cases A(3)-1 and $\mathrm{A}(2)-2$, thus differing from Cases $\mathrm{A}(1)$ and $\mathrm{A}(2)-1$.

Fig. 6 shows two data sets. The open circles show the advancing position $\left(x=x_{e}\right)$ corresponding to the peak in the $\rho_{v}$ vs. $x$ profiles for Case A(3)-1 corresponding to Fig. 3 (radiative heating). Plotted data (open circles) appear to follow a roughly linear relation, $x_{e}=2.25 \sqrt{t}$ in the units of centimeter and hour. Evaporation was likely to occur at this location because of the divergence in

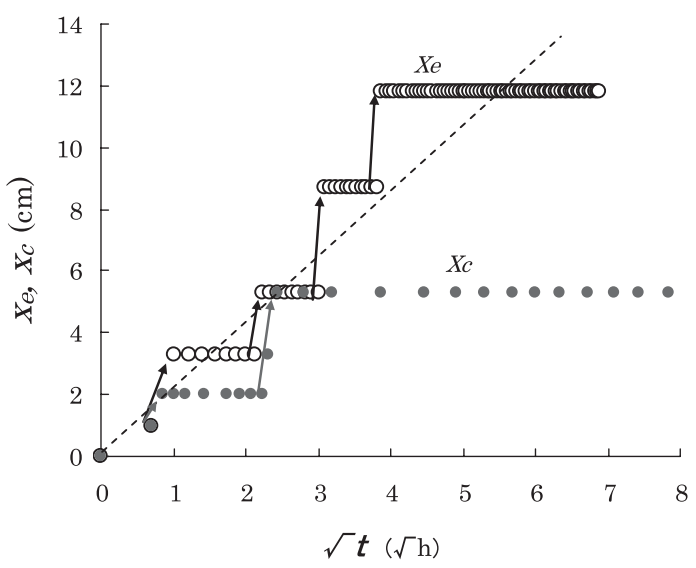

Fig. 6 Movement of the position of $x_{e}$ and $x_{c}$ with time for Cases A(3)-1 and A(3)-2, respectively. The dotted line is a fitted line to data for $x_{e}$.

図－6 Cases A (3)-1 and A (3) -2における $x_{e}$ および $x_{c}$ の 位置の時間変化. 点線は $x_{e}$. に対する回帰直線を 示す. 
vapour flux that exists there due to positive and negative gradients of vapour density on both sides. The origin of the evaporated water is considered to be adsorbed water condensed on sand grain surfaces. This is due to that matric potential $\psi$ for $\mathrm{RH}=65 \%$ as experimentally maximum value and $T=25{ }^{\circ} \mathrm{C}$ was calculated to be $-6.1 \times 10^{5} \mathrm{~cm}$ in water head via Equation (7) (also see Appendix A2) and its gravimetric water content was measured to be 0.0054 in a subsidiary experiment to obtain water retention curve, therefore water in absorbed state exists much more dominantly than in capillary state.

As shown in Fig. 4 (no radiative heating, thus cooling), the vapour density profiles for Case A(3)2 have an upward concave shape. The position of the trough location $\left(x_{c}\right)$ is also plotted using closed circles in Fig. 6. Vapour condensation is expected to occur close to the trough location of vapour density (Fig. 4). The advancement of $x_{c}$ was much slower than for $x_{e}$ and an upper limit critical depth $(\sim 6 \mathrm{~cm})$, was likely to exist. During early stages of the experiment the location of condensation appeared to move downwards in proportion to the square root of elapsed time, as with the evaporation location for Case A(3)-1, though plotted data did not vary smoothly due to discrete humidity measurement. These conditions appear through the influence of thermal radiation alone, suggesting that Equation (10) is applicable within the applied experimental conditions.

\section{$\mathrm{V}$. CONCLUSIONS}

Results obtained from these carefully conducted experiments have provided new insights into the processes of evaporation and condensation in bare soils in arid and semi-arid areas. Experimentally, direct and continuous measurement of vapour density and humidity in the soil were essential and were made using in-profile humidity and temperature sensors. Field investigations of these processes, while important, cannot elucidate detailed mechanisms because of the difficulty in controlling key variables in a field environment.
These experiments have identified the important processes which should suggest methods to achieve validation in the field. The results obtained through these experiments are summarized as follows:

1) Vapour movement in the soil is modeled by a simple diffusion equation with respect to vapour density, (Equation (10)), where the original sink term (see Equations (3) and (4)) is incorporated into a modified, effective diffusion coefficient (Equation (11)) via parameter $\beta$ defined by Equation (9). By comparison of experimentally obtained vapour diffusivity with that calculated via the proposed model, it was found that evaporation and condensation within the profile significantly retarded the movement of the vapour density profile as a breakthrough curve by a factor of roughly 1,000 , in comparison with the simple diffusion process of water vapour without evaporation and condensation.

2) In the experiments simulating simply daytime and nighttime by changing heat application conditions only (Cases A(3)-1 and A(3)-2), evaporation and condensation front were also found to move downward almost in a proportion to a square root of time but development of the latter seemed to be limited. It was recognized from the experiment: that the occurrence of evaporation in daytime causes divergence of the vapor movement in upward and downward directions around the evaporation location, while the condensation in nighttime leads to inversely convergence, accompanied with invasion of atmospheric vapour into the soil layer.

Overall, fundamental vapour behaviour in a dry land, in particular under an isothermal soil condition, has been clarified experimentally. Broadly, it is expected that the experimentally obtained concept may make an effective contribution to understand an important vapourrelated process in water balance and ecology in arid area, for example, by taking account of suggestions on importance of the direct water vapour adsorption to soils in such dry environments by Agam and Berliner (2006). 


\section{Acknowledgements}

This research was supported by Grant-in-Aid for Scientific Research C(2) (No.15560447 (20032004)) in Japan Society for the Promotion of Science.

\section{Appendix}

\section{A-1: Reduction of Equation (8)}

If $\psi$ in Equation (7) is assumed to be a unique function of $\theta$, it is obtained from Equation (7) that:

$$
\frac{\partial \theta}{\partial t}=\frac{\frac{1}{\rho_{v}} \frac{\partial \rho_{v}}{\partial t}-\left(\frac{1}{\rho_{v s}} \frac{d \rho_{v s}}{d T}-\frac{g}{R} \frac{\psi}{T^{2}}\right) \frac{\partial T}{\partial t}}{\frac{g}{R T} \frac{d \psi}{d \theta}}
$$

In Equation (1A), only when $\frac{\partial T}{\partial t}$ can be assumed to be negligibly small, $\frac{\partial \rho_{v}}{\partial t}$ is connected with $\frac{\partial \theta}{\partial t}$ as:

$$
\frac{\partial \theta}{\partial t}=\beta \frac{\partial \rho_{v}}{\partial t}
$$

where $\beta$ is defined in Eqn.(9). Therefore substitution of Equation (1A) into Equation (6) yields Equation (8).

\section{A-2: Properties of $\beta$ defined by Equation (9)}

As the water retention curve ( $\psi$ vs. $\theta$ ) is considered to be simply described by (e.g., Campbell, 1985):

$$
\psi=\psi_{e}\left(\frac{\theta}{\theta_{s}}\right)^{-b}
$$

where $\psi_{e}$ is the air-entry value, $\theta_{s}$ is $\theta$ at saturation and $b$ is a constant $(>0)$, its application to Equation (9) becomes:

$$
\beta=\frac{\frac{\theta_{s}}{b m \rho_{v s}}}{F\left(\psi_{r}\right)}
$$

where $\psi_{r}=\psi / \psi_{e}(\geq 1), \mathrm{F}\left(\psi_{r}\right)=\psi_{r}{ }^{1+1 / b} \mathrm{e}^{-m \cdot \psi r}$ and $m=-\frac{\psi_{e} g}{R T}$. In Equation (4A), $\psi_{e}$ is assumed constant, because surface tension for a non-uniform

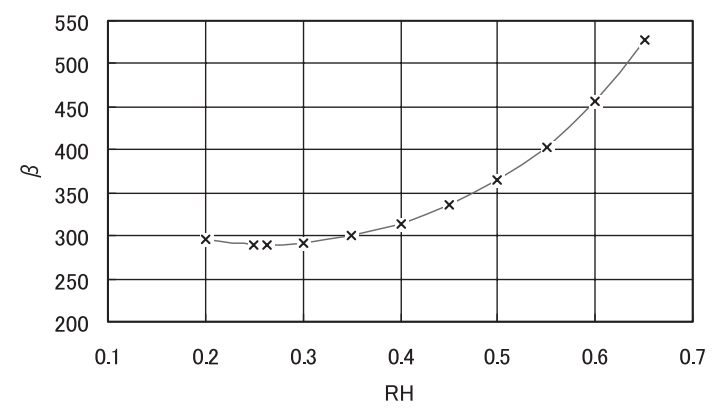

Fig. A1 $\beta$ vs. RH, where unit of $\beta$ is $\mathrm{cm}^{3} / \mathrm{g}$. 図一A1 $\beta$ とRHの関係. ここに, $\beta$ の単位は $\mathrm{cm}^{3} / \mathrm{g}$ である.

temperature distribution between $25{ }^{\circ} \mathrm{C}$ and $40{ }^{\circ} \mathrm{C}$ as stated in TEXT (Section of Experimental result) was calculated to vary by only $3 \%$ (e.g. American Institute of Physics, 1972).

Equation (4A) suggests that $\beta\left(\psi_{r}\right)$ has an upward concave shape giving a minimum at $\psi_{r}=$ $(1+1 / b) / m\left(=\psi_{r}^{*}\right)$. As for the employed sandy soil, where $b=3$ and $\psi_{e}=-10 \mathrm{~cm}$ are used, $\psi_{r}{ }^{*}$ is calculated to be $1.88 \times 10^{5}$, when $T=300 \mathrm{~K}$ and $R$ $=4.615 \times 10^{6} \mathrm{erg} /(\mathrm{gK})$ are set. Also the relative humidity (RH), $h$, for this $\psi_{r}{ }^{*}$ was calculated to be 0.264 via Equation (7), where atmospheric boundary conditions of $\mathrm{RH}, h=0.2$ and 0.65 in the experiment, corresponding to $\psi_{r}=2.27 \times 10^{5}$ and $6.08 \times 10^{4}$, respectively, were employed. Overall, by using $\theta_{s}=0.4$ and $\rho_{v, s}=23 \times 10^{-6} \mathrm{~g} / \mathrm{cm}^{3}$ in Equation (4A), as seen in Fig. A1, $\beta$ varies with respect to $h$ as: it hardly decreased from $h=0.2$ to $h=0.264$ and increased from $h=0.264$ to $h=0.65$, but practically $\beta$ starts to increase from about $h=0.4$. This suggests that $D_{v} / D_{v, m}=300-500$ under the condition that $\theta_{a} \ll \rho_{w} \beta$ in Equation (2).

\section{REFERENCES}

Agam N, Berliner PR. 2004. Diurnal water content changes in the bare soil of a coastal desert. Journal of Hydrometeorology 5: 922-933.

Agam N, Berliner PR. 2006. Dew formation and water vapor adsorption in semi-arid environments-a review. Journal of Arid Environments 65: 572-590. DOI:10.1016/j.jaridenv.2005.09.004. American Institute of Physics. 1972. Handbook, 3rd Edition. McGraw-Hill: New York; 2-206.

Barnes CJ, Allison GB. 1984. The distribution of deuterium and ${ }^{18} \mathrm{O}$ in dry soil. 3. theory for non-isothermal water movement. Journal of Hydrology 74: 119-135. DOI:10.1016/0022-1694(84)90144-6.

Campbell GS. 1985. Soil physics with basic - transport models 
for soil-plant systems. Developments in Soil Science 14, Elsevier: Amsterdam; 43-44.

Chanzy A, Bruckler L. 1993. Significance of soil surface moisture with respect to daily bare soil evaporation. Water Resources Research 29: 1113-1125. DOI:10.1029/92WR02747.

Crank J. 1975. The Mathematics of Diffusion, 2nd Edition. Oxford University Press: New York; 20-21.

de Vries D.A. 1963. Thermal properties of soils. In Physics of Plant Environment, van Wilk WR. (ed). North-Holland Publish Company: Amsterdam; 220.

Ishihara Y, Shimojima E, Harada H. 1992. Water vapour transfer beneath bare soil where evaporation is influenced by a turbulent surface wind. Journal of Hydrology 131: 63-104. DOI:10.1016/0022-1694(92)90213-F.

Mitsuta Y, Tamagawa I, Sahashi K, Wang J. 1995. Estimation of annual evaporation from the Linze Desert during HEIFE. Journal of the Meteorological Society of Japan 73: 967-974.
Philip JR, de Vries DA. 1957. Moisture movement in porous materials under temperature gradients. Transaction, American Geophysics Union 38: 222 - 232.

Shimojima E, Tamagawa I, Turner JV. 2010. Experimental investigation of evaporation and condensation in sandy soils under simulated arid conditions. Proceeding Papers, 7th IAHS International Groundwater Quality Conference (GQ10), Zurich, Switzerland: TU-01.

Yamanaka T, Yonetani T. 1999. Dynamics of the evaporation zone in dry sandy soils. Journal of Hydrology 217:135-148. DOI:10.1016/S0022-1694(99)00021-9.

Zhang Q, Song L, Hunng R, Wei G, Wang S, Tian H. 2003. Characteristics of hydrologic transfer between soil and atmosphere over Gobi near oasis at the end of summer. Advances in Atmospheric Science 20: 442-452.

(受付：2010年8月24日，受理：2011年2月4日)

\title{
模擬乾燥地条件下の砂質土壌での蒸発一凝結に関する実験的検討
}

\author{
下島栄一1）玉川一郎 2） ジェフリー・V・ターナー3) \\ 1) 大同大学 \\ (テ457-8532 名古屋市南区白水町40) \\ 2) 岐皁大学流域圈科学研究センター \\ ( テ501-1193 岐皁市柳戸1-1) \\ 3) CSIRO Land and Water \\ (PO Wembley 6913, Western Australia)
}

乾燥地域での日周期的な気象条件による土中の水蒸気の挙動特性を明らかにするために, 西オーストラリアの塩 分を含む砂質土䁃によるカラム実験を，制御された大気条件下で実施した，砂柱の上表面は，一定温度 $\left(25^{\circ} \mathrm{C}\right)$ で あるが，熱照射付与の有無の条件で，相対湿度が $20 \%$ \% $65 \%$ ， あるいは逆の方向に階段的に変化する一定湿度を もつ大気に開放して実験を行った，さらに，相対湿度 65 \%の大気条件下，照射条件のみ階段的に与えた後，停止す るという実験ケースも同様に行ったが，それぞれは昼間及び夜間に対応している。

大気の湿度のみ階段的に変化させるとき, 土䁃中の水蒸気密度 $\rho_{v}$ は $x / \sqrt{t}(x:$ 深さ, $t:$ 経過時間 $)$ の関数に従って変 化する。この特性やこれと関係する結果は，本論文で提案される $\rho_{\mathrm{v}}$ に関する等温条件下の修正水蒸気拡散方程式を 介して説明された。実験的に評価された水蒸気拡散係数とモデル計算との比較によって, 土㙵層内の蒸発と凝結によ り破過曲線としての水蒸気密度分布の移動は顕著に遅延されることが分かった．実験を通して明らかにされた水蒸気 の挙動特性は, 乾燥地での地面と大気間のみならず地中での水分輸送の挙動を理解する上で重要となる.

キーワード : 蒸発, 凝結, 乾燥域, 水蒸気輸送, 土壤カラム実験 